\title{
İklim Değișikliğinin Aydın Yöresinde Toprak Nemi Üzerindeki Etkileri ve SWAP Modeli ile Simülasyonu
}

\author{
Yıldırım KAYAM*1 \\ Gönül Bilgehan AYDIN² \\ 'European Commission, Joint Research Center, Ispra, Italy \\ ${ }^{2}$ Adnan Menderes Üniversitesi, Ziraat Fakültesi, Toprak Bilimi ve Bitki Besleme Bölümü, Aydın, Türkiye \\ *Sorumlu yazar e-posta (Corresponding author e-mail) : ykayam@gmail.com
}

DOI: 10.21657/topraksu.338304

Öz

Bu çalıșma, küresel ısınmadan kaynaklanan iklim değișikliğinin çevreye olan etkilerinden birisi olan tarımsal alanlardaki toprak nemi üzerine odaklanmıștır. IPCC'nin dördüncü Değerlendirme Raporunda, olası iklim değișikliği senaryoları arasında öncelikli olarak belirtilen A1B iklim projeksiyonuna dayalı olarak, Akdeniz havzasında olușabilecek iklimsel değișiklikler, Aydın yöresindeki tarımsal alanlardaki toprak nemi ile ilișkilendirilmiștir. Yağıș ve sıcaklık bașta olmak üzere iklim rejiminin değișmesi, toprakta depolanan nemde ve yerüstü/yer altı su kaynaklarında önemli değișmelere neden olacaktır. Bu çalıșmada, iklim senaryoları ve öngörüler ıșığında Akdeniz havzasında olușabilecek değișmelerin toprak nemi üzerindeki etkileri agrohidrolojik bir model ile simule edilmiș, daha sonra gelecekte öngörülen olası değișmelere göre söz konusu model çalıștırılarak senaryo analizleri yapılmıștır. Çalıșmada SWAP modeli kullanılımıș ve modelin gerektirdiği toprak, iklim ve bitkiye ilișkin veri seti hazırlanarak, yazlık ürün yetiștirme dönemi boyunca Aydın yöresinde yer alan toprak tipi ve katmanlarına göre toprak nem değișimleri tahmin edilmiștir. Senaryo analizlerinden elde edilen sonuçlara göre, sıcaklık artıșı ile birlikte topraktan olan buharlașma ve bitkiden olan terlemenin potansiyel olarak önemli oranda artacağı ve bu talebi karșılamak üzere, yüksek taban suyu olan yörede kapilar yükselme ile bitki kök bölgesine doğru hızlı bir su hareketi olacağı tahmin edilmiștir.

Anahtar Kelimeler: Aydın, iklim değișikliği, SWAP model, toprak nemi

\section{The Effects of Climate Change on Soil Moisture in Aydın Region and Simulation by SWAP Model}

\begin{abstract}
This study has focused on soil moisture in agricultural lands which affected by environmental effects of climate change due to global warming. Climatic changes that may occur in the Mediterranean basin based on the A1B climate projection of IPCC which is primarily indicated among possible climate change scenarios in AR4, have been associated with soil moisture in the agricultural areas of Aydın province. The change of climate regime which mainly deal with rainfall and temperature, will cause significant changes for moisture stored in the soil and also for surface and ground water resources. In this study, the effects of climate change on soil moisture were simulated by an agrohydrological model, and then some definitive scenario analysis performed by this model in the light of climate change projections for Mediterranean region. The SWAP model was used with a data set of soil-climate-plant, and the soil moisture was monitored according to soil properties of the layers in a selected area on an alluvial soil in the province of Aydın during the summer cultivation period of the year of 2012. According to the results from scenario analysis, it was estimated that the evaporation from soil and transpiration from plants will increase potentially and there will be a water movement upward from high water table to the root zone to meet this increasing demand.
\end{abstract}

Key Words: Aydın, climate change, SWAP model, soil moisture 


\section{Giriș}

Küresel Isınmadan kaynaklanan iklim değișikliğinin, bașta yağıș ve sıcaklık olmak üzere, küresel ve bölgesel düzeylerde bütün iklimsel parametreleri doğal değișkenliğin ötesinde etkileyeceği ve yeryüzünde binlerce yıldır hüküm süren iklimi ve dolayısıyla hayatı değiștireceği bilim insanları tarafından dile getirilmektedir 12007 yılında dördüncüsü yapılan Hükümetler Arası İklim Değișikliği Paneli bünyesinde yayınlanan Bölgesel İklim Projeksiyonları çerçevesinde (Șekil 1), Avrupa ve Akdeniz Bölgesi İklim Projeksiyonlarına ayrılan bölümde uzmanlar tarafından bazı öngörüler yapılmıș ve yayınlanmıștır). Buna göre; Avrupa'da yıllık ortalama sıcaklıkların, küresel ortalamadan daha fazla artacağı, Kuzey Avrupa'da ısınmanın daha çok kıș mevsiminde, Akdeniz bölgesinde ise yazın olușacağı bildirilmiștir. Yapılan öngörüler dikkate alındığında, yıllık yağıșların muhtemelen kuzey Avrupa'nın çoğu yerinde artacağı, Akdeniz bölgesinde ise azalacağı tahmin edilmektedir. Ayrıca, Akdeniz bölgesinde yağıșlı günlerin sayısında da bir azalmanın olacağı ve yaz mevsiminde olușacak kuraklık riskinin artacağı farklı senaryolarda dile getirilmiștir (IPCC, 2007a).

Büyük Menderes Havzasının da içerisinde yer aldığı Akdeniz iklim kușağında olușacak iklim değișiklikleri sonucunda, özellikle yaz aylarındaki sıcaklık artıșı ile birlikte kıș yağıșlarındaki azalma ve kuraklık riskinin, tarımsal üretimi doğrudan etkileyeceği tahmin edilmektedir. Bütün bu iklimsel değișmenin öncelikle su kaynakları üzerindeki etkileri, farklı yöntem ve teknikler kullanılarak dünyada ve Türkiye'de tahmin edilmeye çalıșılmaktadır. Ancak, iklim değișikliğinin topraktaki etkileri üzerinde yapılan çalıșmaların nispeten daha az sayıda ve sera etkisini artıran $\mathrm{CO}_{2}$ salınımı ile organik ve inorganik karbon döngüsüne yönelik olduğu dikkati çekmektedir. Buna karșın, gerek toprakta karbon döngüsünde birinci derecede etkisi olan organik maddenin parçalanması ile atmosfere tașınan $\mathrm{CO}_{2}$ miktarı, gerekse bitkisel verimliliğe ve üretim desenine etkisinin oldukça fazla olduğu bilinen toprak nemi konusu, hala üzerinde çalıșılması gereken en önemli konular arasında yer almaktadır.

İklim değișiklikleri sonucunda gerçekleșmesi olası sıcaklık artıșı ve yağıș azalması, toprak nem içeriğini doğrudan etkileyen parametrelerdir. Bitki gelișim periyodu boyunca bitki için gerekli nemin toprakta yeterli miktarda bulunması, verim açısından çok önemlidir. Bu nedenle, ülkemizin yılda birden fazla ürün alınan ve yoğun tarım yapılan Büyük Menderes Havzasında yer alan Aydın yöresinde iklim değișikliğinin toprak nem rejimleri üzerine etkilerinin araștırılması büyük önem arz etmektedir.

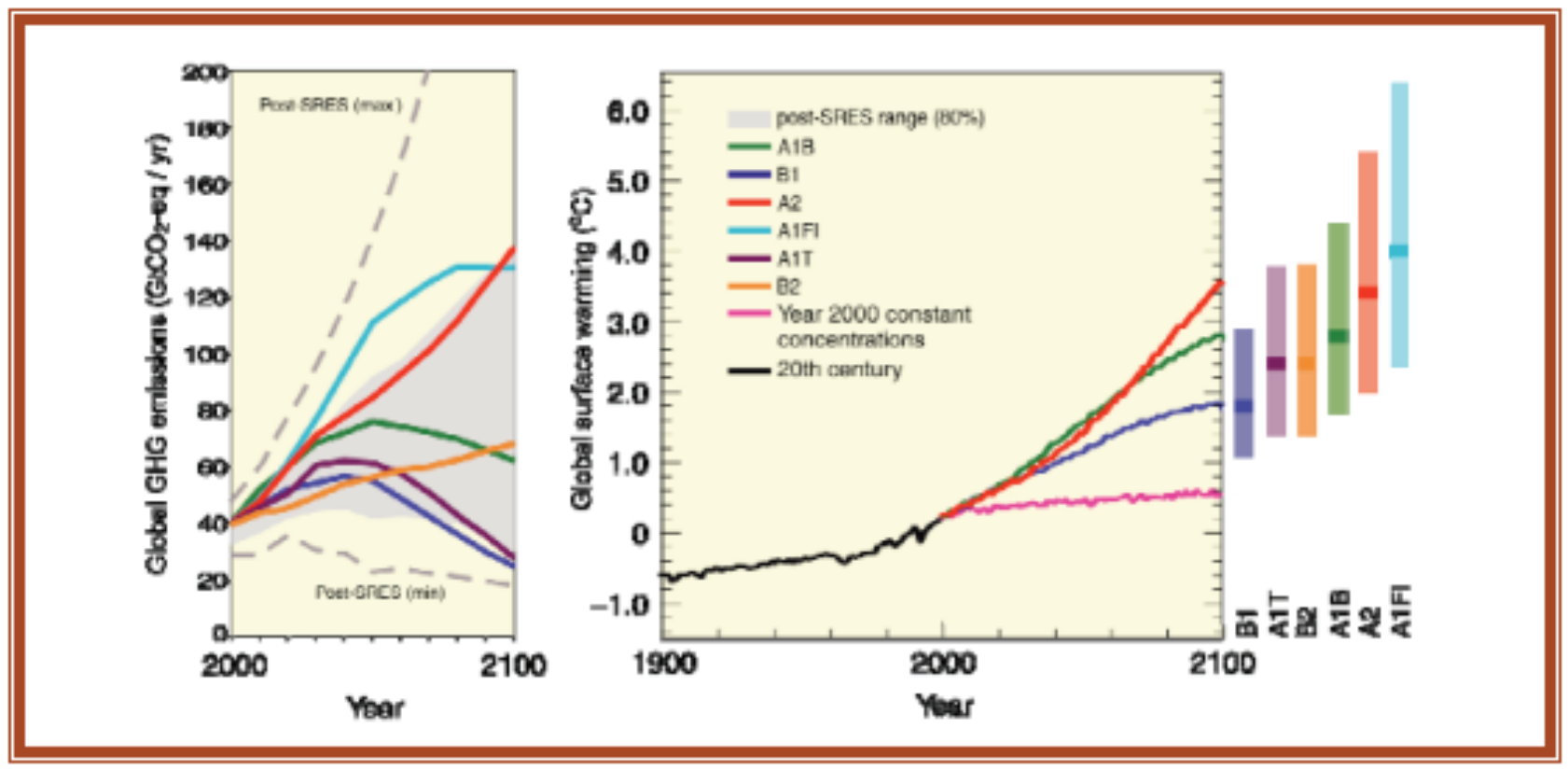

Șekil 1. GHG emisyonları için (iklim politikalarının uygulanmadığı durumda) 2000'den 2100'e senaryolar ve yüzey sıcaklıkları artıșları için projeksiyonlar (IPCC, 2007a)

Figure 1. Scenarios for GHG emissions from 2000 to 2100 (in the absence of additional climate policies) and projections of surface temperatures increases (IPCC, 2007a) 
Bu çalıșmada, olası bölgesel iklim değișikliği senaryolarına dayalı olarak, Aydın yöresinde örnek bir alanda yağıșlar ve sulama uygulamaları ile toprakta depolanan nemdeki değișimler fiziksel bir model kullanılarak incelenmiș ve önemli sonuçlara ulașılmıștır. Bu amaçla, olası iklim değișikliği senaryolarına göre toprak nem dengesi ve evapotranspirasyon, toprak ve bitki özellikleri kullanılarak noktasal düzeyde ve amaçlar doğrultusunda analiz edilmiștir.

Konu ile ilgili yapııımıș çalıșmalar, iklim değișikliği ve toprak nemi modelleme çalıșmaları olmak üzere ayrı olarak değerlendirilmiștir.

Kömüșçü (1998), Güneydoğu Anadolu Bölgesindeki toprak nemi için iklim değișiminin sonuçlarını incelemiștir. Çalıșmada, Willmot (1997) tarafından orijinal Thorthwait su dengesi modelinin bilgisayar uygulamalı versiyonu kullanılmıștır. Senaryolar; +2 ve $+4{ }^{\circ} \mathrm{C}$ sıcaklık artıșı ile $-\% 20$, -\%10, \%0, +\%10, +\%20 yağıș değișikliklerinin kombinasyonlarını içermiștir. Isınma senaryolarına dayanarak, \% 20 daha fazla yağıș durumunun bile toprak nemleri üzerindeki etkisinin sınırlı olduğu, bir bașka değișle öngörülen sıcaklık artıșlarının evapotranspirasyonu önemli ölçüde artırdığı ve bunun da yaz aylarında toprakta nem açığını artırdığını bildirmiștir.

Robock vd., (2000) toprak neminin dünyadaki iklim sisteminin, özellikle su döngüsü açısından en önemli bileșenlerinden biri olduğunu belirtmișlerdir. Toprak neminin bu denli önemli olmasına karșın, dünyada çok az lokasyonda uzun dönemli ve düzenli olarak ölçüldüğünü bildirmișlerdir.

Kayam vd., (2002a) tarafindan yürütülen istatistiksel bir çalıșmada, Ege Bölgesinde 19701999 yıllarını kapsayan dönemdeki sıcaklık ve yağıșlardaki değișmenin buğday üretimi üzerindeki etkilerini incelenmiștir. Bu çalıșmada, aylık yağıșlarda \% 5 ve \% 10'luk azalmalar ile aylık ortalama sıcaklıklarda $+1{ }^{\circ} \mathrm{C}$ ve $+2{ }^{\circ} \mathrm{C}$ 'lik artıșları içeren dört farklı iklim senaryosu hazırlanmıș ve analiz edilmiștir. Buna göre, Nisan ve Mayıs aylarında yağan yağıșlarda miktarsal olarak \% 5 azalma olduğunda, buğday verimlerinde ortalama $13,1 \mathrm{~kg} \mathrm{ha}^{-1}$ ve \%10'luk bir azalma olduğunda ise $22,9 \mathrm{~kg} \mathrm{ha}^{-1}$ 'llk bir verim azalması meydana gelmiștir.

Kayam vd., (2006) tarafından yürütülen ve Ege Bölgesinde pamukta uzun dönemli istatistiksel verilerin, araștırma sonuçları ile entegre edilerek yeniden analiz edildiği bir çalıșmada, 4 farklı ilde 29 yıllık veriler ile bölgede yürütülen pamuk denemelerine ilișkin 1027 adet parsel sonuçları, iklimin ve toprak koșulları ile çeșit özellikleri de dikkate alınarak pamuk verimleri üzerindeki etkileri araștırılmıștır. Modelde, 1969-1970 ile 1989-1999 aralığında toprak nem dengesi zaman serileri ile simüle edilmiștir. Bu çalıșmanın sonuçlarına göre, bir pamuk tarlasındaki mevsimlik su dengesi, bir önceki kıș yağıșlarından etkilenmekte ve özellikle kurak bir yılı takip eden yağıșlı bir yılda bu etki açık olarak görülmektedir.

Șen (2006), iklim değișiminin toprak nemi üzerindeki lokal etkilerinin, yalnızca iklim değișiminin derecesi ile değil, aynı zamanda toprak özellikleri ile de farklılık göstereceğini bildirmiștir.

IDKK (2006), iklim Değișikliğinin Etkilerinin Araștırıması Çalıșma Grubu tarafindan yazılan çalıșma raporunda, "Duyarlılık analizleri, İklim Değișikliğinin Etkileri ve Uyum Önlemleri" değerlendirilmiștir. Özellikle sıcaklık ve yağıștaki değișmelerin Türkiye üzerindeki olası etkileri ele alınarak, yıllık ortalama sıcaklıkların 2050 yılına kadar, yalnız sera gazlarındaki artıșlar dikkate alındığında, $1-3{ }^{\circ} \mathrm{C}$ arasında; sera gazlarındaki ve sülfat parçacıklarındaki değișimler birlikte dikkate alındığında ise $1-2{ }^{\circ} \mathrm{C}$ arasında bir artıș olacağı öngörüldüğü bildirilmiștir.

IPCC (2007a), küresel ısınma kaynaklı iklim değișikliğinin Türkiye için en önemli etkisi, çoğu bölgelerde yağıșın azalması ile ortaya çıkacak olan kuraklık ve su kaynaklarında azalma șeklinde olacağı bilim adamları tarafından bildirilmektedir. Dördüncüsü yapılan Hükümetler Arası İklim Değișikliği Paneli (IPCC)'nin sonuçları 2007 Nisan ayı itibariyle yayınlanmıș bulunmaktadır. Buna göre, Güney Avrupa ve Akdeniz bölgesinde (SEM) önümüzdeki 25-30 yıl içerisinde yağıșların mevsimlere göre \% 6 ile \% 53 arasında azalabileceği öngörülmektedir. Olası iklim değișikliği senaryoları arasında bölgemiz açısından da dikkate alınan AlB senaryosu altında simule edilen Güney Avrupa ve Akdeniz alanı için ve 1980-1999 aralığından 2080-2099 aralığına kadar yıllık ortalama ısınmanın $2.0{ }^{\circ} \mathrm{C}$ 'den $5.1{ }^{\circ} \mathrm{C}$ 'ye kadar değișeceği öngörülmektedir. Bu durumun, en çok su kaynaklarını ve rezervlerini etkileyeceği tahmin edilmiștir. 
Kanber vd., (2007) kurak alanlarda küresel ısınmanın neden olduğu iklim değișiminin tarımsal üretim sistemleri üzerine etkilerini araștıran bir projeyi Seyhan havzasında yürütmüșlerdir. Bölgesel model sonuçlarına göre, söz konusu dönemde Seyhan havzasında aylık ortalama sıcaklıkların $3^{\circ} \mathrm{C}$ artacağı; yıllık yağıș miktarında ise \%25'lik bir azalma olacağı saptanmıștır. Potansiyel evapotranspirasyonda \%14'lük bir artıș, buna karșı gerçek evapotranspirasyonda ise, yağıșın azalmasına bağlı olarak, \% 1 7'lik bir azalıșın olacağı kestirilmiștir.

Aydın vd., (2008) Japonya'da geliștirilen bir bölgesel iklim modeli ile 2070'lerde Akdeniz bölgesinde \% 46 civarındaki yağıș azalmasına dayalı olarak çıplak topraktan olan buharlașmanın 50 mm kadar düșmesi (\% 16,5 azalma) ile gelecekte toprak neminin de azalacağı öngörülmüștür.

İklim değișikliğinin etkileri kapsamında, Türkiye'de tarım sektöründeki etkilere yönelik çalıșmaların büyük bölümü yerel ölçekli olmakla birlikte, az sayıda makro ölçekli çalıșmalar da yapılmıștır. Yerel düzeydeki çalıșmalardan birinde, Trakya Bölgesi'nde (Kırklareli), Buğday bitkisinin karbondioksit ve meteorolojik faktörlerdeki değișimden nasıl etkilenebileceği araștırılmıștır (Çaldağ ve Șaylan, 2005). Araștırmada, bir bitkiiklim modeli kullanılarak iklim değișikliğinin buğday bitkisi üzerine etkileri çalıșılmıștır. Kadıoğlu ve arkadașlarının çalıșması (2004), iklim değișikliğinin Türkiye'nin su kaynaklarına potansiyel etkilerini içermektedir. Meteoroloji Genel Müdürlüğünce hazırlanmıș olan Türkiye'nin 1971-2000 ve 2007 kuraklık haritaları incelendiğinde sıcaklık artıșlarına paralel olarak Türkiye'de ciddi anlamda bir kuraklık tehlikesinin bulunduğu ortaya çıkmaktadır. Orta Anadolu ve Ege Bölgesinin de bu kuraklıktan belirgin olarak payını alacağı beklenmektedir (Uğurlu ve Örçen, 2007).

Bastiaansen vd., (1996) tarafından, HindistanHaryana bölgesinde son yirmi yıl içinde sulanan alanlarda meydana gelen hızlı artıșın, bölgesel su ve tuz bilançosuna ilișkin dengeleri bozduğu belirlenmiștir. Bu çalıșmada su ve tuz dengesi, kısa süreli nem ve eriyik iletim modeli olan SWAP ile analiz edilmiș ve model simülasyonları, Haryana'daki bütün tarımsal iklim bölgeleri için gerçekleștirilmiștir.

Kite ve Droogers (2000) tarafindan kaleme alınan bir derleme, gerçek buharlașma ve terlemeyi tahmin etmek için 8 farklı yöntemi içeren ve farklı araștırmacılar tarafından gerçekleștirilen araștırmaya genel bir bakıș sağlamaktadır. Araștırma, nispeten daha geleneksel yöntemler ile yeni geliștirilen yöntemleri karșılaștırmak için 1998 yaz boyunca Türkiye'nin batısında (Menemen) yürütülmüștür. Denemede SWAP modeli, 1998 yllında 9 aylık bir periyodda bir pamuk tarlası için ve farklı ürünlerin bulunduğu bir vadi tabanı için çalıștırımıștır.

Droogers (2000), farklı ölçeklerde suyun verimliliğini değerlendirmek amacıyla iki adet havza ölçekli model (WSBM-SLURP) ve bir adet ayrıntılı tarla ölçekli model (SWAP) olarak, Türkiye ve İran'dan iki farklı havzayı karșılaștırmıștır. Ele alınan iki havzanın, iklim ve su yönetimi açısından tamamen farklı yapıya sahip olduğu vurgulanmıștır. Havza ölçeğinde su verimlilik değerleri, İran için 0,45 $\mathrm{kg} \mathrm{m}^{-3}$ ve Türkiye için ise $0,17 \mathrm{~kg} \mathrm{~m}^{-3}$ bulunmuștur.

Kayam vd., (2002b) tarafindan Gediz Havzası Entegre Araștırma Projesi bünyesinde 1998 yılında yürütülen bir çalıșmada, sulanan bir alanda topraktaki su dengesine ilișkin bütün bileșenleri analiz etmek amaciyla tek boyutlu bir model (SWAP) kullanılmıștır. Beș farklı ürün ve dört farklı toprak tipi bileșimini içeren alanın, toprak- su dengesi açısından incelendiği çalıșmada, kuraklık öncesi dönemde așırı sulamalar nedeniyle derine sızmaların ve alt akımların meydana geldiği; kurak dönemde ise bu akımın negatif yönde olduğu ve kılcal yükselmelerin bitki kök bölgesine katkıda bulunduğu ortaya konulmuștur.

Droogers ve Van Dam (2002), California, Sacremento havzasında yürütülen ve su kaynakları, gıda ve çevrenin iklim değișikliğine adaptasyonu konulu çalıșmada, tarla ölçeğinde SWAP modeli ile analizler ve öngörüler gerçekleștirmișlerdir. Bu çalıșmanın sonuçları, çeltik verimlerinde A2 iklim senaryosuna göre $\% 50$ artıș ve B2 senaryosuna göre ise \%20 artıș beklenebileceğini ortaya koymuștur. Araștırmacılar, bu artıșların atmosferdeki $\mathrm{CO}_{2}$ düzeylerinin artmasından ileri gelebileceğini belirtmișlerdir.

Korkmaz vd., (2009) Ege bölgesinde Menemen Sol Sahil Sulama Sisteminin sekonder ve tersiyer kanal düzeyinde su dağıtım performansını ve agro-hidrolojik su dengesini 2005-2006 yılları için değerlendirmișlerdir. Bu çalıșmada, tarla düzeyinde su dengesine ilișkin bütün bileșenlerin 
analiz edilmesi amacıyla tek boyutlu fiziksel bir model olan SWAP benzeșim modeli uygulanmıștır. Bu amaçla belirlenen alanlardaki örnek parsellerde ekimden-hasada kadar olan üretim dönemi boyunca, giren ve çıkan akımlar simüle edilmiș ve toprakta dönemsel su dengesi bileșenleri elde edilmiștir.

\section{MATERYAL VE YÖNTEM}

Araștırma, Adnan Menderes Üniversitesi Ziraat Fakültesi Araștırma ve Uygulama Alanında kurulan pamuk ekili deneme parselinde yürütülmüștür. Deneme alanı Büyük Menderes Nehrinin aktivitesi sonucu olușmuș alüviyal topraklar üzerinde yer almakta olup, ova topraklarının genel özelliklerini temsil etmektedir.

İklim Özellikleri ve toprak profili dikkate alındığında Xerofluvent büyük grubunda yer alan deneme alanı toprakları, 0-90 cm toprak profili boyunca horizon esasına göre dört farklı katman içermekte olup, hafif ve orta hafif bir bünyeye sahiptir. 0-90 cm'de toplam yarayıșlı nem, 170,6 mm olarak bulunmuștur. Hacim ağırlığı değerleri ise, 1,47 ile 1,65 gr $\mathrm{cm}^{-3}$ arasında değișmektedir. Çalıșmada olușturulan gözlem ve test parselinde, verim potansiyeli yüksek ve çıçır randımanı nispeten yüksek olan ve olumsuz çevre koșullarına dayanıklı olan Claudia çeșidi pamuk tohumu kullanılmıștır (Anonim, 2013). Çalıșma alanının içerisinde yer aldığı Aydın ilinde, Akdeniz iklimi hakimdir. Alt bölgeler arasında belirgin bir farklılık görülmeyen ilde, yazlar sıcak ve kurak, kıșlar ise ılık ve yağıșlıdır. IIIde en yüksek sıcaklık Temmuz, en düșük sıcaklık ise Ocak aylarında görülmektedir. Yılık sıcaklık ortalaması 17,6 ${ }^{\circ} \mathrm{C}$ 'dir. Araștırma alanının çok yıllık yağıș ortalaması 619,8 mm olup, en fazla yağıș verisi Aralık ayında ölçülmüștür. (DMi, 2012).

Çalıșmada, ülkelerin ekonomik gelișmelerine dayalı sera gazı emisyonlarına bağlı olarak olușturulan iklim değișimi senaryoları çerçevesinde, IPCC 2007 raporlarında öncelikli olarak belirtilen A1B'e dayalı bölgesel iklim projeksiyonu temel alınmıștır. Buna göre projeksiyonlar, 1980-1999 aralığından 20802099 aralığına kadar Güney Avrupa - Akdeniz bölgesi (SEM) için bir Çoklu Model Veri Seti (MMD) içerisindeki 21 adet küresel modeli kapsayan öngörülere dayanılarak olușturulmuștur. Çizelge I'de gösterildiği gibi bu set içerisindeki modellerin küresel ısınmaya verdikleri tepkiler, sıcaklık ve yağıștaki olası değișmeler olarak maksimum, minimum, medyan ile \%25'lik ve \%75'lik çeyrekler șeklinde gösterilmiștir. Buna göre, Güney Avrupa ve Akdeniz bölgesi için sıcaklık öngörüleri yıllık ortalama olarak 2,2 Co ' den 5, 1 Co 'ye ve yağıștaki azalmalar ise \%4'ten \%27'ye kadar bir değișiklik göstermiștir. Negatif ișaretli değerler \% azalma olarak ifade edilmiș, ekstrem sezonların oranı ise, 21 modelin en az 14'ü önemli çıktığında yüzdesel

Çizelge 1. AlB senaryosu için 21 küresel modelden gelen sıcaklık ve yağıș öngörülerinin Kuzey Avrupa ve Güney Avrupa / Akdeniz bölgeleri düzeyinde mevsimlik ortalamaları (IPCC, 2007b)

Table 1. Regional averages of temperature and precipitation projections for North Europe and South Europe/Mediterranean from a set of 21 global models for the AlB scenario (IPCC, 2007b)

\begin{tabular}{|c|c|c|c|c|c|c|c|c|c|c|c|c|c|c|c|c|}
\hline \multirow{2}{*}{ Bölge } & \multirow{2}{*}{$\begin{array}{c}\text { Ay } \\
\text { Mevsim }\end{array}$} & \multicolumn{5}{|c|}{ Sıcaklık Tepkileri $\left(\mathrm{C}^{0}\right)$} & \multicolumn{6}{|c|}{ Yağıș Tepkileri $\left(\mathrm{C}^{0}\right)$} & \multicolumn{4}{|c|}{ Ekstrem sezonlar (\%) } \\
\hline & & Min & 25 & 50 & 75 & Maks & Tyıl & Min & 25 & 50 & 75 & Maks & Tyıl & Ilık & Nemli & Kuru \\
\hline \multicolumn{17}{|c|}{ AVRUPA } \\
\hline \multirow{5}{*}{$\begin{array}{l}\text { Kuzey Av. } \\
40 N, 10 W \\
\text { ve } \\
75 N, 40 E \\
\text { arasında }\end{array}$} & AOS & 2,6 & 3,6 & 4,3 & 5,5 & 8,2 & 40 & 9 & 13 & 15 & 22 & 25 & 50 & 82 & 43 & 0 \\
\hline & MNM & 2,1 & 2,4 & 3,1 & 4,3 & 5,3 & 35 & 0 & 8 & 12 & 15 & 21 & 60 & 79 & 28 & 2 \\
\hline & HTA & 1,4 & 1,9 & 2,7 & 3,3 & 5,0 & 25 & -21 & -5 & 2 & 7 & 16 & & 88 & 11 & \\
\hline & EEK & 1,9 & 2,6 & 2,9 & 4,2 & 5,4 & 30 & -5 & 4 & 8 & 11 & 13 & 80 & 87 & 20 & 2 \\
\hline & Yıllık & 2,3 & 2,7 & 3,2 & 4,5 & 5,3 & 25 & 0 & 6 & 9 & 11 & 16 & 45 & 96 & 48 & 2 \\
\hline \multirow{5}{*}{$\begin{array}{l}\text { Güney Av. } \\
\text { ve Akdeniz } \\
30 \mathrm{~N}, 10 \mathrm{~W} \\
\text { ve } \\
48 \mathrm{~N}, 40 \mathrm{E} \\
\text { arasında }\end{array}$} & AOȘ & 1,7 & 2,5 & 2,6 & 3,3 & 4,6 & 25 & -16 & -10 & -6 & -1 & 6 & $>100$ & 93 & 3 & 12 \\
\hline & MNM & 2,0 & 3,0 & 3,2 & 3,5 & 4,5 & 20 & -24 & -17 & -16 & -8 & -2 & 60 & 98 & 1 & 31 \\
\hline & HTA & 2,7 & 3,7 & 4,1 & 5,0 & 6,5 & 15 & -53 & -35 & -24 & -14 & -3 & 55 & 100 & 1 & 42 \\
\hline & EEK & 2,3 & 2,8 & 3,3 & 4,0 & 5,2 & 15 & -29 & -15 & -12 & -9 & -2 & 90 & 100 & 1 & 21 \\
\hline & Yıllık & 2,2 & 3,0 & 3,5 & 4,0 & 5,1 & 15 & -27 & -16 & -12 & -9 & -4 & 45 & 100 & 0 & 46 \\
\hline
\end{tabular}


bir değer almıștır (IPCC, 2007b).

Bu çalıșmada, Çizelge 2, 3 ve 4'te gösterildiği șekliyle 3 adet senaryo Aydın bölgesi için yukarıdaki çizelgeye dayanılarak olușturulmuștur. Buna göre, bölgedeki mevsimsel sıcaklık ve yağıș değișimleri, (ekstrem sezonlar da dikkate alınarak ve bağımsız olarak) en çok, en az ve orta düzeyli tepkiler olarak senaryo analizine girmiș, dağılımda \%25'lik ve \%75'lik çeyreklere ilișkin değerler ise senaryo olușumuna dahil edilmemiștir. Söz konusu iklim değișimi senaryoları çerçevesinde yağıș ve sıcaklık öngörüleri, yöre için henüz ölçek küçültücü bir model bulunmaması nedeniyle aylık bazda mevsimsel olarak çalıșılmıștır. Yalnızca Senaryo 3 için iki varsayım dikkate alınmıștır; mevcut iklimsel öngörüler ıșığında taban suyunun yörede öngörülen düzeyde var olduğu (Senaryo 3a) ve taban suyunun olmadığı (veya çok derinde) serbest drenajın söz konusu olduğu (Senaryo 3b) duruma göre analiz yapıımıștır.

Deneme alanı topraklarından horizon esasına göre alınan bozulmuș ve bozulmamıș toprak örneklerinde toprak bünyesi, hacim ağırlığı, tarla kapasitesi ve devamlı solma noktası gibi analizler (Tüzüner, 1990) yapılmıștır. Ayrıca, doygun ve doygun olmayan koșullarda hidrolik iletkenlik ve farklı hidrolik yüklerde toprak nem düzeyleri gibi hidrolik özellikler pedotransfer fonksiyonları kullanılarak modelleme yolu ile tahmin edilmiștir (Van Genuchten, 1980). Deneme parselinde her sulama öncesi ve yaklașık on günlük aralıklarla nem izlemesi ve taban suyu gözlemleri yapılmıștır. Toprak nem düzeyleri; araziden horizon esasına göre alınan toprak örneklerinde nemli toprak ağırlığından $105^{\circ} \mathrm{C}$ 'de etüvde kurutulmuș toprak ağırlığının çıkarılmasından, gravimetrik olarak saptanmıștır. Taban suyu düzeyleri ise, gözlem alanının yakınına çakıımıș olan bir taban suyu gözlem kuyusu (piyozometre) ile elde edilmiștir. Bitki veri seti ile ilgili olarak yetișme dönemi uzunluğu; pamukta ekim tarihinden ilk hasat tarihine kadar olan uzunluk (gün), bitki boyu; ilk kotiledon yaprak boğumundan büyüme noktasına kadar olan yükseklik (m) olarak ve toprağı kaplama oranı; pamuk gelișme dönemlerine

Çizelge 2. Projede Senaryo 1 için temel alınan Çoklu Model Veri Setine göre en az etki olasılıklı öngörüler

Table 2. The projections for Scenario 1 based on the minimum responses according to Multi Model Dataset

\begin{tabular}{lcc}
\hline Mevsimler ve Aylar & Sıcaklıkta değișmeler $\left({ }^{\circ} \mathrm{C}\right)$ & Yağıșta değișmeler $(\%)$ \\
\hline Kıș (Aralık-Ocak-Șubat) & 1,7 & 6 \\
İlkbahar (Mart-Nisan-Mayıs) & 2,0 & -2 \\
Yaz (Haziran-Temmuz-Ağustos) & 2,7 & -3 \\
Sonbahar (Eylül-Ekim-Kasım) & 2,3 & -2 \\
\hline
\end{tabular}

Çizelge 3. Projede Senaryo 2 için temel alınan ve Al B için olușturulan Çoklu Model Veri Setine göre orta derecede etki olasılıklı öngörüler

Table 3. The projections for Scenario 2 based on the medium responses according to Multi Model Dataset for AlB

\begin{tabular}{lcc}
\hline Mevsimler ve Aylar & Sıcaklıkta değișmeler $\left({ }^{\circ} \mathrm{C}\right)$ & Yağıșta değișmeler (\%) \\
\hline Kıș (Aralık-Ocak-Șubat) & 2,6 & -6 \\
İlkbahar (Mart-Nisan-Mayıs) & 3,2 & -16 \\
Yaz (Haziran-Tem.-Ağustos) & 4,1 & -24 \\
Sonbahar (Eylül-Ekim-Kasım) & 3,3 & -12 \\
\hline
\end{tabular}

Çizelge 4. Projede Senaryo 3 için temel alınan ve AlB için olușturulan Çoklu Model Veri Setine göre en fazla etki olasılıklı öngörüler

Table 4. The projections for Scenario 3 based on the maximum responses according to Multi Model Dataset for AlB

\begin{tabular}{lcc}
\hline Mevsimler ve Aylar & Sıcaklıkta değișmeler $\left({ }^{\circ} \mathrm{C}\right)$ & Yağıșta değișmeler (\%) \\
\hline Kıș (Aralık-Ocak-Șubat) & 4,6 & -16 \\
İlkbahar (Mart-Nisan-Mayıs) & 4,5 & -24 \\
Yaz (Haziran-Tem.-Ağustos) & 6,5 & -53 \\
Sonbahar (Eylül-Ekim-Kasım) & 5,2 & -29 \\
\hline
\end{tabular}


(FAO, 1998) göre toprağı gölgeleme oranı esas alınarak belirlenmiștir. Bitki kök gelișimi, deneme alanından seçilen örnek bitkilerin kök gelișimi kesit alınarak gözlenmiștir.

Araștırmanın yürütüldüğü alana ait 2012 yılı iklim verileri (maksimum ve minimum sıcaklık, solar radyasyon, nispi nem, rüzgar hızı ve yağıș), pamuk gelișme dönemi olan Mayıs-Ekim ayları arasındaki dönem için Adnan Menderes Üniversitesi Araștırma ve Uygulama Çiftliğinde yer alan meteoroloji istasyonundan günlük olarak elde edilmiștir. Deneme parseline 1 Mayıs 2012 tarihi itibariyle pamuk ekimi yapılmıș ve gübreleme, çapalama ve sulama uygulamaları yörede yaygın teknikler kullanılarak yürütülmüștür. Sulamalar, yüzey sulama yöntemi ile çiftçi uygulamaları ve bitki gözlemleri dikkate alınarak, toprak nem durumuna göre farklı miktarlarda uygulanmıștır. Pamuk kozalarının \%50'si açtığında hasat ișlemleri gerçekleștirilmiștir. 2012 yllında yürütülen denemeye ilișkin sulamalar, yörede bulunan çiftçilerin uygulama zamanları dikkate alınarak ve sulama miktarları, topraktaki eksik nemin tarla kapasitesine getirilmesi yoluyla yapılımıstır. Senaryo analizlerinde ise, sulamalar yine elverișli nem düzeyleri temel alınarak ve yürütülen denemeye uygun olarak simüle edilmiștir.

Çalıșma alanında toprak neminin simülasyonu ve olası iklim değișikliğinin toprak nemi üzerindeki etkilerini inceleyecek olan agrohidrolojik analizler, SWAP modeli kullanılarak yapılmıștır. Model, toprak-bitki-atmosfer bileșik sisteminde su döngüsünü simüle etmek amacıyla kullanılmıștır. Burada bulunan yaklașımlar, bu çalıșmanın esasını olușturmuș ve elde edilen sonuçlar olası iklim değișikliğinin toprak nem değișimi ve rejimi üzerindeki etkilerini yorumlama da kullanılmıștır. SWAP modelinde, toprak profilindeki su hareketini tanımlamak için, yer alan Richards denklemi kullanılmaktadır. Richards denkleminin sayısal çözümü, Belmans (1983) tarafından tanımlandığı șekliyle farklı durumlara uyarlanmıștır. SWAP modelinde, tarla düzeyinde toprak heterojenliği ele alınmaktadır. Kullanıcı, model içerisinde çok sayıda ölçüt faktörleri sağlayabilme olanağına sahiptir. Bu faktörler; buharlașma, toprak profilinin geometrisi, toprağın fiziksel parametreleri, köklenme derinliği, histeresis, sulama programı, toprak yarıklarından geçen akım ve bașlangıç nem durumu gibi faktörlerdir. SWAP modelinde yer alan iki farkı bitki modülünden biri olan“Basit Bitki Modülü" kullanılmıștır. Bitki ile ilgili birçok veri, 0 - 2 arasında değișen bitki gelișme dönemlerinin bir fonksiyonu olarak belirtilmiștir (Çizelge 5). Bitki verim tepki etmeni katsayıları, bölgede yürütülen bir çalıșma olmaması nedeniyle pamuk için FAO 33 numaralı yayından alınarak, deneme süresince bitki gelișme dönemlerine göre uyarlanmıștır.

SWAP modeli, doygun koșullara sahip sığ toprak katmanı ile derin yeraltı suyu varlığı arasında farklı seçenekler sunmaktadır. Bu seçenekler, alt katmanlarda basınç yükünü ve akımyönü ile birlikte miktarlarını da tahmin etmede kullanılmaktadır. Ayrıca, önceden tanımlanmıș yeraltı su düzeyleri, serbest drenaj ve serbest yanal akımlar gibi farklı seçenekleri de sunmaktadır. Araștırmada, ölçülen taban su düzeyleri $-100 \mathrm{~cm}$ ile $-140 \mathrm{~cm}$ arasında değișiklik göstermiș ve modele veri olarak girilmiștir Çalıșmada serbest drenaj seçeneği, yalnızca Senaryo 3 için uygulanmıștır.

Çizelge 5. Pamuk gelișme dönemlerine dayalı gözlemler, ölçümler ve veriler

Table 5. The observations, measurements and data based on the growing periods of cotton

\begin{tabular}{lccccc}
\hline Tarih & $\begin{array}{c}\text { Bitki Gelișme Dönemleri } \\
(0-2.0)\end{array}$ & $\begin{array}{c}\text { Kaplama Oranı } \\
(\%)\end{array}$ & $\begin{array}{c}\text { Bitki Yüksekliği } \\
(\mathrm{cm})\end{array}$ & $\begin{array}{c}\text { Kök Gelișimi } \\
(\mathrm{cm})\end{array}$ & $\begin{array}{c}\text { Verim tepki } \\
\text { etmeni (ky) }\end{array}$ \\
\hline 01.05 .2012 & 0,00 & 0,00 & 0,00 & 0,00 & - \\
19.06 .2012 & 0,60 & 0,10 & 10,00 & 8,00 & 0,20 \\
16.07 .2012 & 0,90 & 0,35 & 50,00 & 10,00 & 0,20 \\
08.08 .2012 & 1,20 & 0,65 & 86,00 & 20,00 & 0,50 \\
27.08 .2012 & 1,40 & 0,90 & 96,00 & 25,00 & 0,75 \\
13.09 .2012 & 1,60 & 0,97 & 101,00 & 45,00 & 0,75 \\
15.10 .2012 & 2,00 & 0,93 & 105,00 & 60,00 & 0,25 \\
\hline
\end{tabular}




\section{BULGULAR VE TARTIȘMA}

Aydın iklim ve toprak koșullarında 2012 yılı pamukyetișme döneminde yürütülen denemede,

toprak nemleri düzenli aralıklarla ve sulamalar öncesi gravimetrik olarak ölçülmüș, nem bütçesi

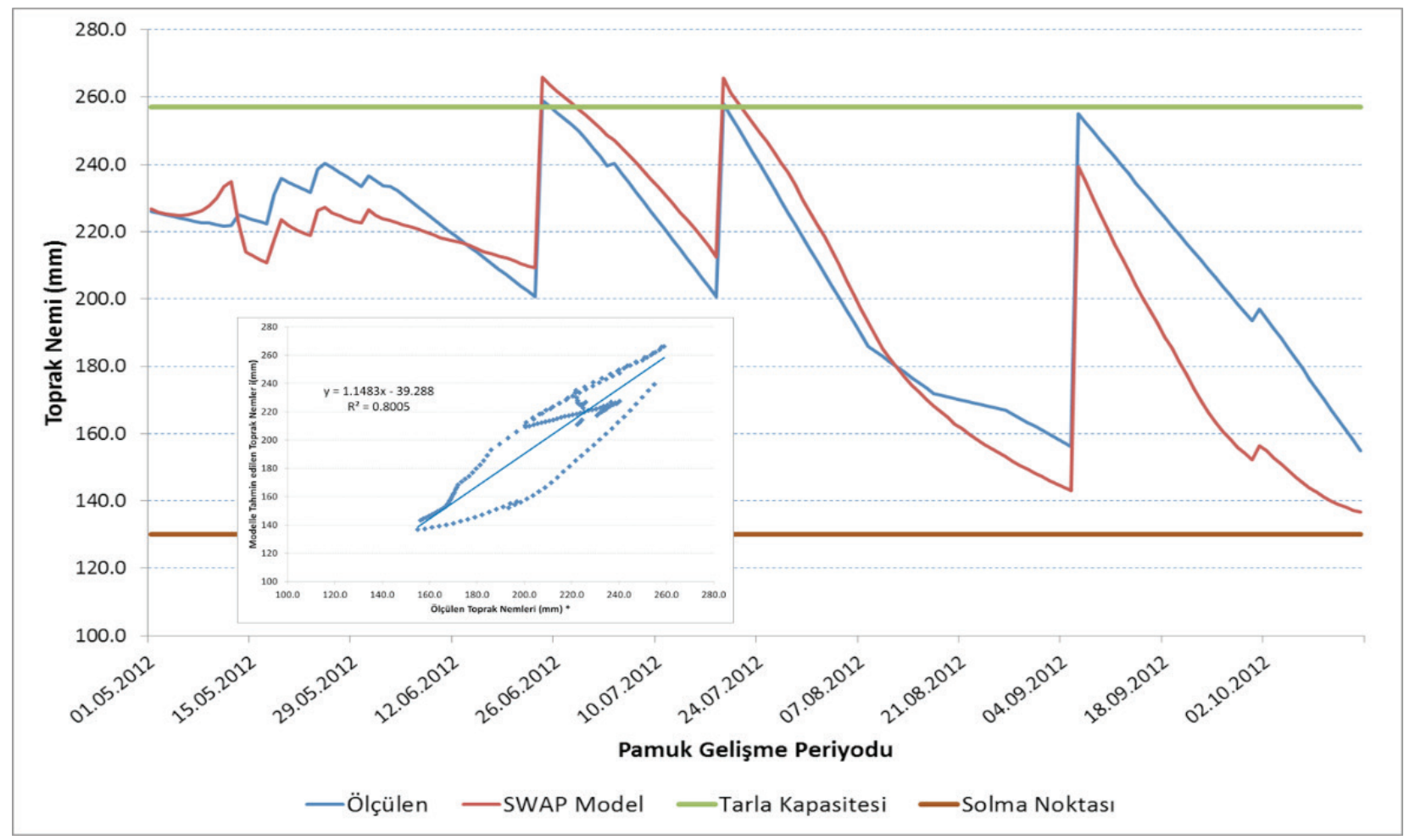

Șekil 2. Yetișme sezonu boyunca ölçülen ve SWAP modeli ile elde edilen toprak nem değerleri

Figure 2. The soil moisture values measured and modelled by SWAP during growing period

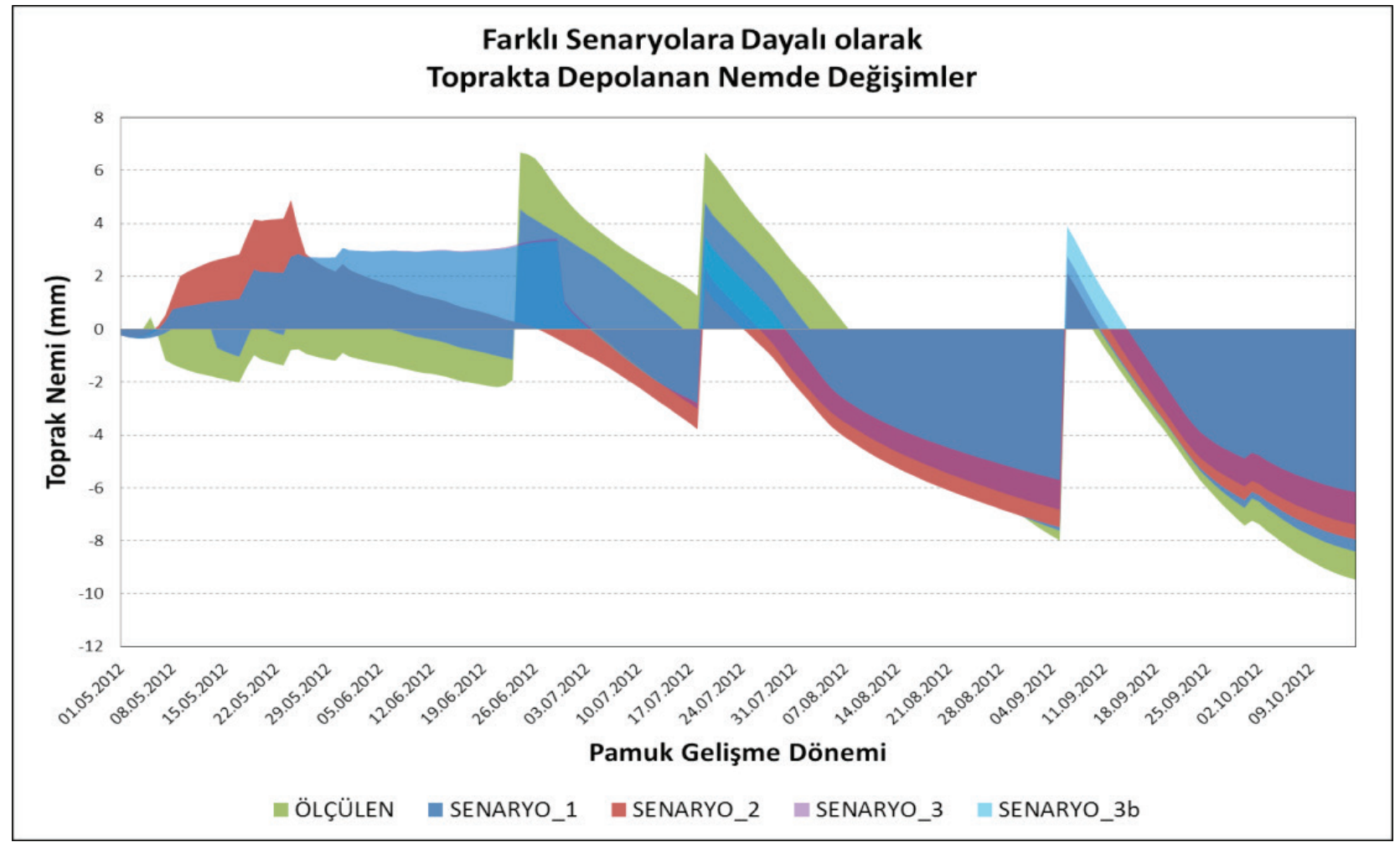

Șekil 3. Ölçülen ve senaryolara dayalı modellenmiș toprak nem değișimleri

Figure 3. Soil moisture changes measured and according to modeled scenarios 
tekniği ile günlük olarak hesaplanarak Șekil 2'de görüldüğü gibi grafiklendirilmiștir. Deneme parseline ilișkin toprak özellikleri, bitki gelișimi ve iklimsel parametrelere ilișkin veriler kullanılarak çalıștırılan ve temel senaryo olarak adlandırılan model çıktısına dayalı toprak nem grafiği de aynı șekil üzerinde gösterilmiștir. Bu iki eğri incelendiğinde, ölçülerek hesaplanmıș toprak nem değerleri ile modelin tahmin ettiği toprak nem değerlerinin birbirine oldukça yakın olduğu görülmüștür.

Yapılan ilișkisel analizde regresyon eșitliği; $y=1,1483 x-39,288 \quad$ olarak bulunmuștur. Ölçülen ve tahmin edilen değerler arasında \% 80 oranında bir uyum olduğu, korelasyon katsayısının $(r=0,90)$ yüksek olması ise, sözü edilen değerler arasında güçlü bir ilișkinin olduğunu göstermektedir.

Elde edilen bu sonuca göre, Aydın iklim ve toprak koșullarında farklı senaryo analizleri yapabilmek ve iklimsel değișimin toprak nemi üzerindeki etkilerini öngörebilmek amacıyla SWAP modelinin kullanılabileceği anlașılmıștır. Model, öngörülen iklim senaryoları çerçevesinde çalıștırılmıș ve toprak nem değișimleri Șekil 3'te ve toprak nemi bileșenlerine ilișkin değerler Çizelge 6'da gösterilmiștir.

Elde edilen bilgilere göre 2012 yılında pamuk yetișme dönemi boyunca, yağıș ve sulamalarla 0-90 cm toprak profiline $275 \mathrm{~mm}$ su giriși olmuș ve sezon içerisinde toplam 47 mm su kök bölgesinden uzaklașmıș olduğu belirlenmiștir. Yüzey akımın olmadığı deneme parselinde bitki yapraklarının engellemesinden ötürü 1,2 mm su toprağa ulașamamıș, ancak buna karșın buharlașma ve terleme yoluyla 334,5 mm nem tüketilmiș, bir bașka değișle atmosfere buhar halinde transfer olmuștur. Sezon sonu itibariyle toprak profilinde depolanan nemde 107,1 mm'lik bir azalmanın olduğu model çıktılarından anlașılmaktadır. Yürütülen denemeye ve diğer senaryolara ilișkin su dengesi bileșenleri, Çizelge 6'da dönemsel olarak sunulmustur. Model çıktıları incelendiğinde; Senaryo l'de iklim öngörülerine uygun olarak bir miktar azalma olmuș, sulama miktarı değișmemiș ve kök bölgesinden ise 40,2 mm su uzaklașmıștır. Toprak profiline giren su miktarındaki azalma oranında evapotranspirasyon miktarı da azalmıștır. Senaryo 2 ve Senaryo 3'te sulama sayısının azalması ve yağıștaki öngörülen azalmaya bağlı olarak, giren su miktarı değișmiș, bu durum kök bölgesinden çıkan yani derine süzülen su miktarında da azalmaya neden olmuștur. Model çıktıları incelendiğinde, senaryolara göre giren akımlar arasındaki farklar $6 \mathrm{~mm}$ ile $22 \mathrm{~mm}$ arasında iken, temel senaryoya göre çıkan akımlarda bu farklar $8 \mathrm{~mm}$ ile $55 \mathrm{~mm}$ arasında olușmuștur. Bu durum, toprakta depolanan nemdeki değișimlere de yansımıștır. Sezon bașında 100 cm toprak profilinde toprak nemi değeri 226 mm olarak hesaplanmıș ve diğer senaryo analizlerinde de bu bașlangıç değeri esas alınmıștır.

Çizelge 6. Farklı senaryolar için SWAP modeli su dengesi bileșenleri

Table $\mathbf{6}$. The water balance components from SWAP model for different scenarios

\begin{tabular}{|c|c|c|c|c|c|}
\hline & Senaryo 0 & Senaryo 1 & Senaryo 2 & Senaryo 3a & Senaryo 3b \\
\hline \multicolumn{6}{|l|}{ Giren Akımlar (mm) } \\
\hline Yağıș & 55,6 & 54,4 & 46,5 & 40,3 & 40,3 \\
\hline Sulama & 220,0 & 220,0 & 160,0 & 170,0 & 230,1 \\
\hline Alt Akım & $-47,0$ & $-40,2$ & $-6,8$ & $-1,4$ & $-64,0$ \\
\hline Toplam & 228,6 & 234,2 & 200,8 & 208,9 & 206,4 \\
\hline \multicolumn{6}{|l|}{ Çıkan Akımlar (mm) } \\
\hline Kesilme & 1,2 & 1,2 & 1,2 & 1,1 & 1,1 \\
\hline Yüzey Akıș & 0 & 0 & 0 & 0 & 0 \\
\hline Transpirasyon & 260,1 & 250,3 & 225,0 & 214,3 & 237,2 \\
\hline Evaporasyon & 74,4 & 76,3 & 68,2 & 65,9 & 74,8 \\
\hline Toplam & 335,7 & 327,8 & 294,4 & 281,3 & 313,0 \\
\hline $\begin{array}{l}\text { Depolanan nemde } \\
\text { değișimler (mm) }\end{array}$ & $-107,1$ & $-93,6$ & $-93,6$ & $-72,4$ & $-106,6$ \\
\hline
\end{tabular}


Pamuk bitkisinin sulanan bir ürün olması nedeniyle toprak nemi, profilde depolanan nem ile birlikte büyük oranda sulama uygulamalarına bağlı olarak değișmiștir. Ancak, yörede taban suyunun yüksek olması $(-120 \mathrm{~cm}$ civarında) nedeniyle taban suyundan olan kapilar yükselme de bitki kök bölgesine sezon boyunca önemli derecede (20 ile $64 \mathrm{~mm}$ arasında) katkıda bulunduğu model çıktılarından anlașılmaktadır.

Yapılan bu çalıșmada, iklimsel senaryolara göre yağıștaki azalmaya bağlı olarak, taban suyu düzeylerinin sırasıyla \%20, \%40 ve \%60 oranında azalması öngörülmüștür. Ölçüm günleri dıșındaki değerler, SWAP modeli tarafından tahmin edilmiștir. Senaryo 1, 2 ve 3 için taban suyu düzeylerinin alt ve üst sınırları sırasıyla 120-168 $\mathrm{cm}$; $140-196 \mathrm{~cm}$ ve $160-224 \mathrm{~cm}$ olarak model tarafından hesaplanmıștır. Senaryolara göre azalan taban suyu düzeyleri dıșında, Senaryo 3 için taban suyunun olmadığı (veya çok derinlerde olduğu) ve serbest drenajın gerçekleștiği bir diğer varsayım da Senaryo 3b olarak adlandırılarak incelenmiștir.

Aydın Ovası iklim ve toprak koșullarında yer alan deneme alanında topraktaki su yüküne ve taban suyu düzeyine bağlı olarak alt akımlar dikey yönde yukarı ve așağı hareket etme eğiliminde olmușlardır. Buna göre alt akımlardaki değișmelere ilișkin model çıktıları, sezon boyunca ve birikimli olarak Șekil 4'te grafiksel biçimde gösterilmiștir.

Ölçülen ve Temel Senaryoya ilișkin alt akımlar incelendiğinde, yağıșlar ve sulamalardan sonra olușan su yükü nedeniyle așağı doğru bir akımın oluștuğu, diğer günlerde ise taban suyundan kapilar yükselmenin etkisi ile yukarı doğru bir akımın mevcudiyeti Șekil 4'teki model çıktısından görülmektedir. Senaryo l'e dayalı model çıktısında, yağıșlı günler öncesi dıșında toprak su hareketinde bir denge durumu olduğu dikkati çekmektedir. Senaryo 2'de ise, artan atmosferik buharlașma talebinin etkisi ile özellikle sulamalar öncesinde önemli bir kapilar yükselme olması öngörülmektedir. Senaryo 3a'da yine sıcaklık artıșından kaynaklanan buharlașma talebi nedeniyle Temmuz ayının bașına kadar, yukarı doğru bir akım tahmin edilmiștir. Bu ise, kök bölgesinde olușan nemlilik nedeniyle ilk sulamanın gecikmesi sonucunu doğurmuștur. Genel olarak bakıldığında, temel senaryo için kapilar yükselme ile kök bölgesine yaklașık 18 mm nem sağlandığı hesaplanmıștır. Bu katkı Senaryo 1

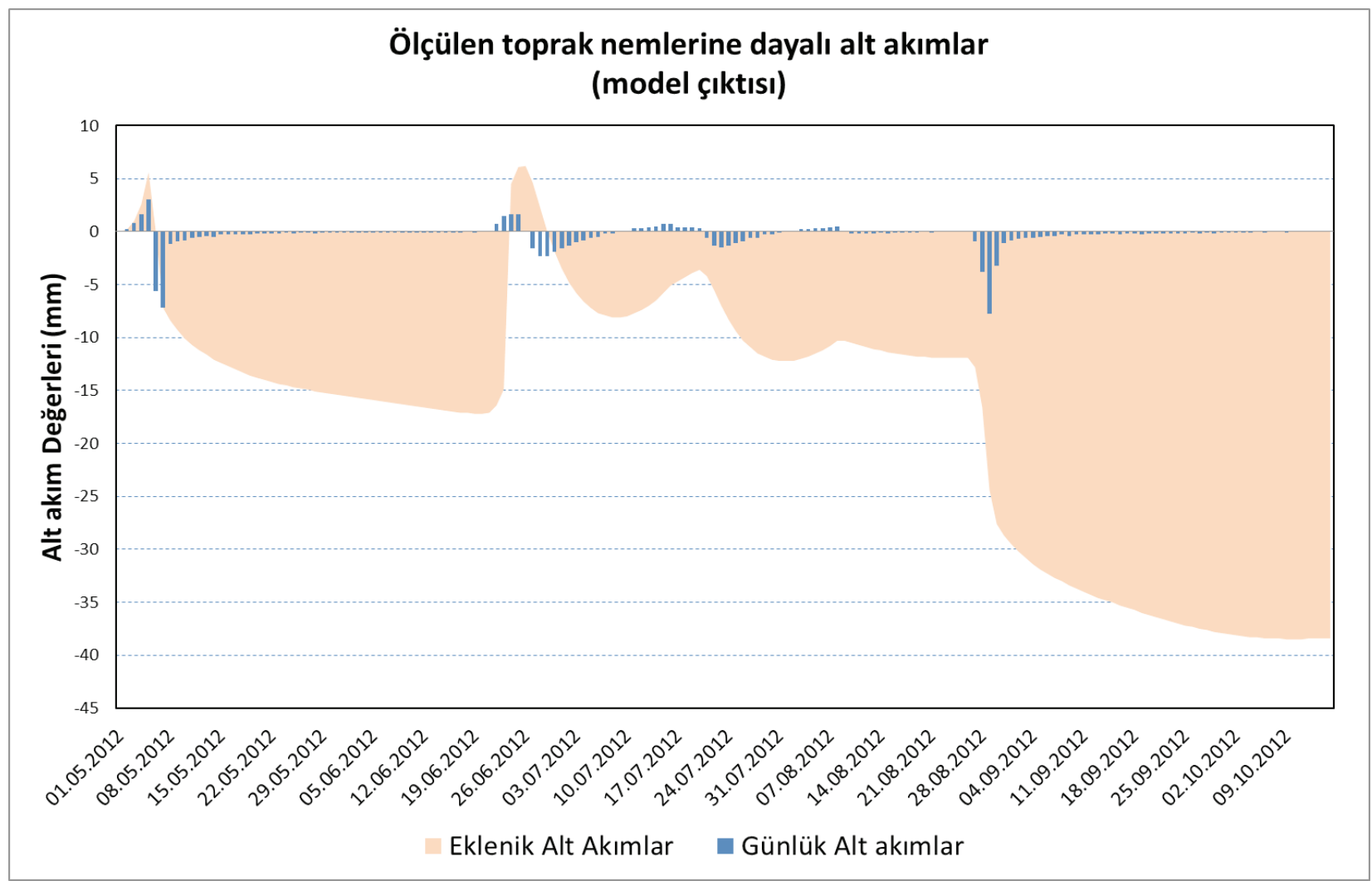

Șekil 4. SWAP modelinde ölçülen toprak nemlerine dayalı günlük ve birikimli akımlar

Figure 4. Daily and cumulative flows based on measured soil moistures by SWAP model 


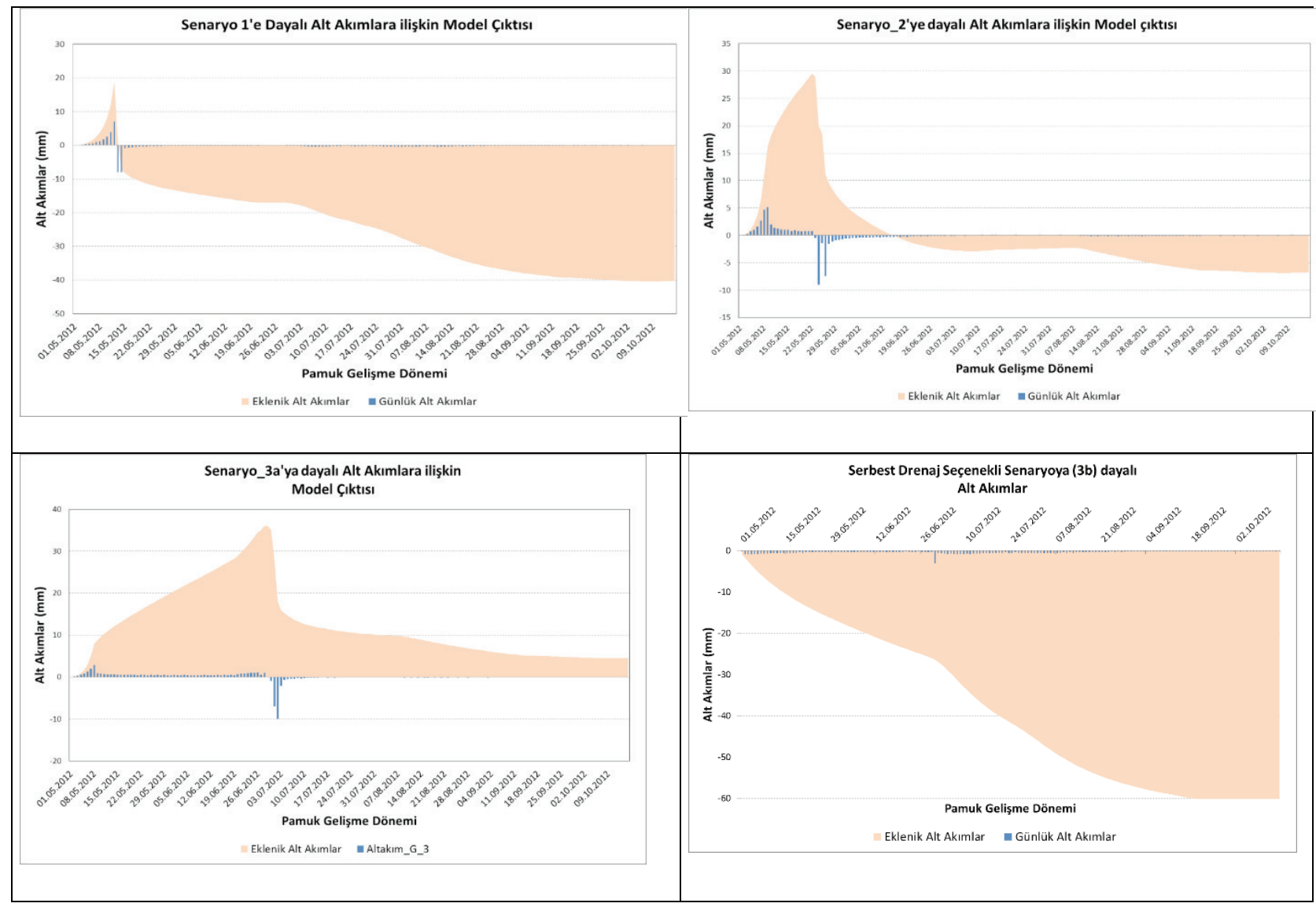

Sekil 5. SWAP modelinde senaryolara dayalı günlük ve birikimli akımlar

Figure 5. Daily and cumulative flows relating to the scenarios by SWAP model

\section{iklimsel Senaryolara Dayalı Maksimum ve Minimum Sıcaklık Öngörüleri}

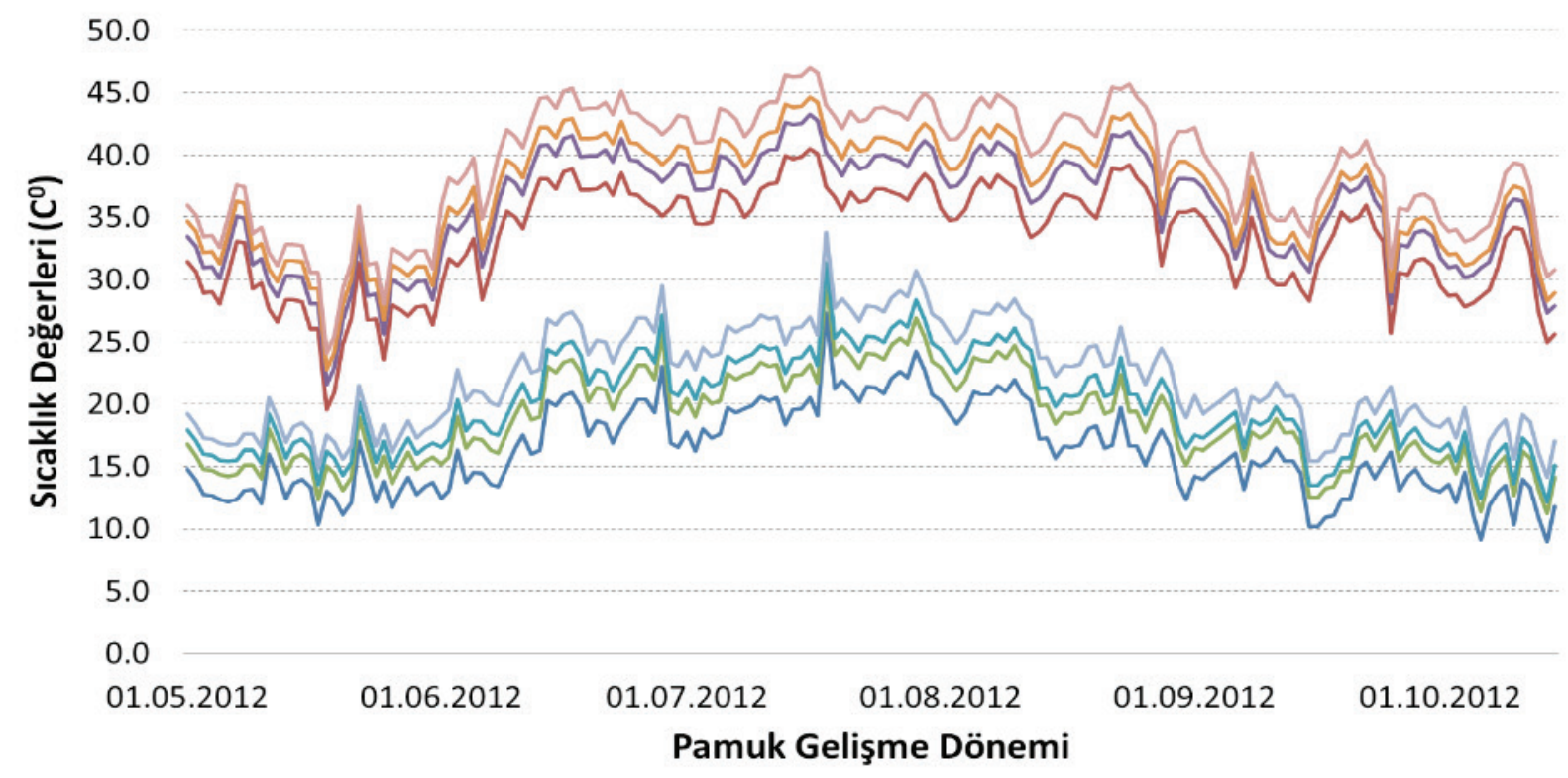

-Tmin_SB - Tmax_SB-Tmin_S1 - Tmax_S1 - Tmin_S2 - Tmax_S2 - Tmin_S3 - Tmax_S3

Șekil 6. Aydın yöresinde pamuk bitkisi gelișme dönemi boyunca sıcaklık öngörüleri

Figure $\mathbf{6}$. The temperature projections during ther cotton growing period in Aydın region 
için 20 mm, Senaryo 2 için 49 mm ve Senaryo 3a için ise yaklașık $64 \mathrm{~mm}$ civarında olmuștur. Serbest Drenaj seçenekli senaryoda (3b) ise alt akımların yönü așağı doğru olmuștur.

\section{İklimsel Analizler}

Pamukyetișme sezonu için öngörülen sıcaklıklar, denemenin yürütüldüğü 2012 yılına ait sıcaklık değerleri baz alınarak tahmin edilmiștir. İklimsel senaryolara dayalı günlük maksimum ve minimum sıcaklık öngörüleri Șekil 6’da gösterilmiștir.

A1B İklim Projeksiyonlarına göre sıcaklıktaki değișme öngörüleri temel alınarak mevsimsel olarak tahmin edilmiș ve ilkbahar döneminde mayıs ayı, yaz döneminde haziran-temmuz-ağustos ayları ile sonbahar dönemindeki eylül-ekim aylarına ilișkin sıcaklık tahminleri farklı olarak hesaplanmıștır. Șüphesiz iklim parametreleri açısından her yıl kendine özgü olup, ayrı olarak değerlendirilmesi gereklidir. Ancak çalıșmada 2012 yılı günlük iklim değerlerinin uzun yılları temsil ettiği varsayılarak diğer iklim öngörüleri bu yıla dayandırılmıștır.

\section{Referans Evapotranspirasyon}

Referans Evapotranspirasyonu tahmin etmede dünyada en çok kabul gören ve FAO tarafından modifiye edilmiș olan Penman-Monteith ETo eșitliği kullanılmıștır. ReferansET'ningünlükolaraktahmini, genel olarak iklimsel parametrelerin buharlașma ve terlemeyi ne ölçüde etkilediği konusunda bir fikir vermekte ve ayrıca bitki katsayılarının kullanılması yoluyla farklı bitkilerin gerçekleștirdiği potansiyel evapotranspirasyonun tahmin edilmesinde araștırmacılara yardımcı olmaktadır. Bu çalıșmada, Referans ET'nin hesaplanmasında kullanılan iklimsel parametrelerden yalnızca maksimum ve

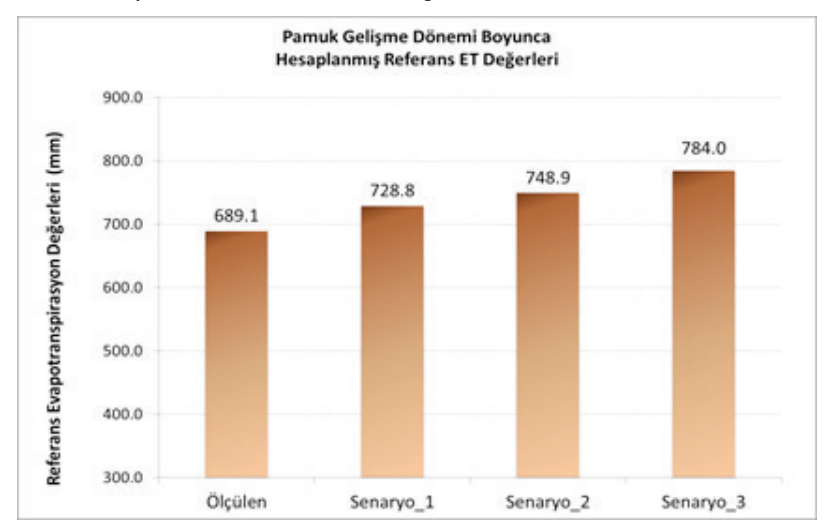

Șekil 7. Pamuk gelișme döneminde senaryolara göre hesaplanmıș referans ET değerleri

Figure 7. The values of Reference ET for the scenarios during the cotton growing period minimum sıcaklıkların senaryolar temel alınarak değiștiği, diğer parametrelerin ise değișmediği varsayılmıștır. Ancak sıcaklık değișimleri, yalnızca buharlașmayı ve terlemeyi etkileyen bir parametre olmayıp, aynı zamanda atmosferin tașıyabileceği nem miktarını ve dolayısıyla buhar basıncını da etkileyen bir parametre olması nedeniyle önem arz etmektedir. Pamuk gelișme dönemi boyunca hesaplanmıș toplam Referans ET değerleri Șekil 7'de gösterilmiștir. Senaryolara göre hesaplanmıș olan Ref ET değerlerinin, 2012 yılına göre oldukça farklı değerler aldığı görülmektedir. Buna göre, Senaryo 1 için 39,7 mm, Senaryo 2 için 59,8 ve Senaryo 3 için ise 94.9 mm kadar farklılașma göstermesi, potansiyel tüketimin artıș oranı hakkında bize bir fikir vermektedir.

Baz yıl olan 2012 yılı ile kıyaslandığında olușturulan farklı senaryolara göre, atmosferin toplam buhar basıncı açığının sırasıyla \%16, \%24 ve \% 41 oranında artacağı tahmin edilmiștir. Bu ise doğrudan atmosferin buharlașma talebi anlamına gelmekte ve gelecekte olușacak su talebi hakkında bilgi vermektedir. Gelecekte, topraktan olan buharlașma ve bitkiden olan terlemenin yüksek oranda artacağı, bitki kök bölgesinde bulunan toprak neminin kısa sürede önemli miktarda azalacağı öngörülmektedir. Taban suyunun var olduğu ve düzeyinin de yüksek olduğu koșullarda ise, bitki kök bölgesine doğru hızlı bir su hareketi olacağı tahmin edilmektedir. Öngörülen bu iklim koșulları, șüphesiz taban suyu düzeyinin düșmesine de neden olacaktır. Taban suyunun yüksek olduğu koșullarda, kapilar yükselme oranının yüksek olmasının, beraberinde tuzlulașma riskini de getireceği de unutulmamalıdır. Buna karșın, yüksek taban suyunun bulunmadığı koșullarda,

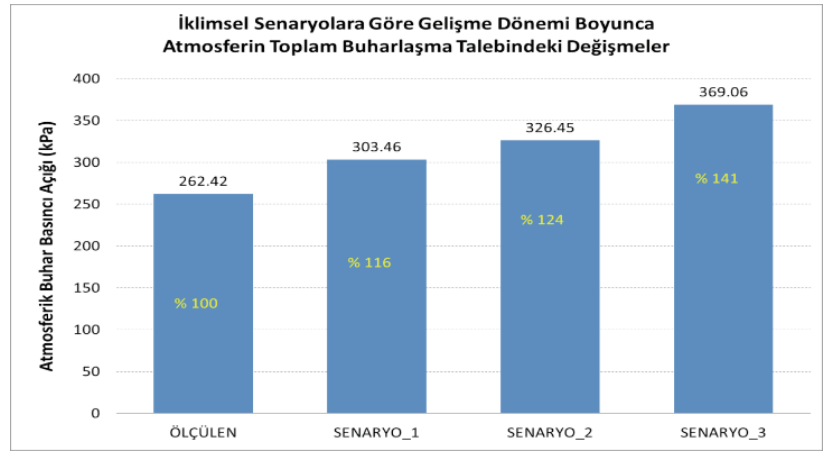

Șekil 8. İklimsel Senaryolara göre gelișme dönemi boyunca atmosferin toplam buharlașma talebindeki değișmeler

Figure 8. The total evaporation demand of atmosphere for the scenarios during the cotton growing period 


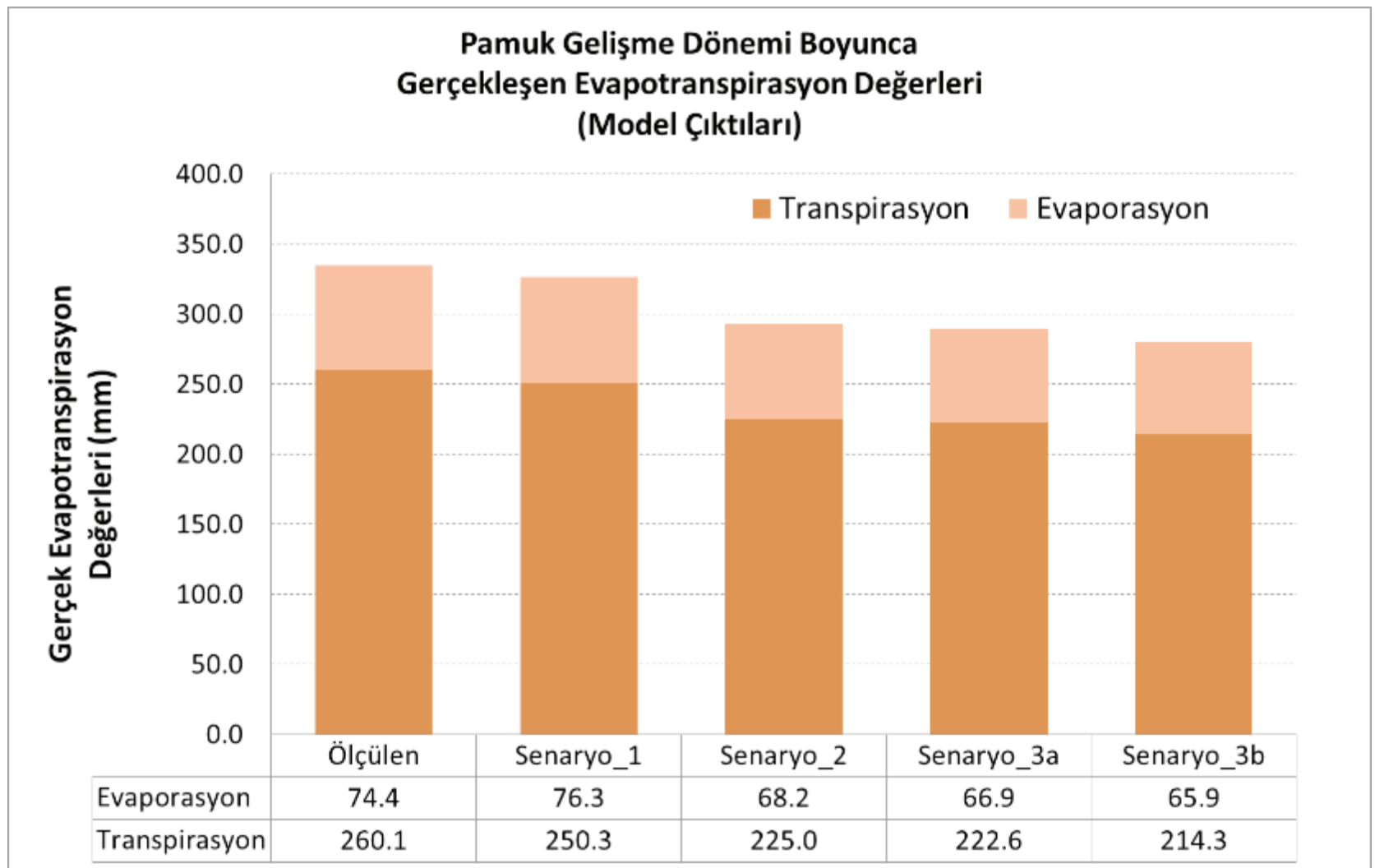

Șekil 9. Pamuk gelișme dönemi boyunca SWAP modeli tarafından tahmin edilen gerçek buharlașma ve terleme değerleri Figure 9. Actual evaporation and transpiration amounts estimated by the SWAP model during the cotton growing period

bitkilerin gelișebilmesi için sulama suyu sağlama olanaklarının geliștirmesi ve daha çok sulama suyu sağlanması bir zorunluluk olduğu açık olarak görülmektedir.

Yürütülen çalıșmada, ölçülen verilere dayalı model sonucuna göre mevsimlik evapotranspirasyon değeri, 334,4 mm olarak hesaplanmıș ve topraktan olan buharlașma miktarı $74.4 \mathrm{~mm}$; bitkiden olan terleme miktarı ise $260,0 \mathrm{~mm}$ olarak bulunmuștur (Șekil 9). Diğer senaryolar için toplam Evapotranspirasyon değerleri; Senaryo 1 için 326,6 mm; Senaryo 2 için 293,2 mm; Senaryo 3a için 289,5 mm ve Senaryo 3b için ise $280,2 \mathrm{~mm}$ olarak tahmin edilmiștir. Atmosferin buharlașma talebinin ve buna dayalı olarak potansiyel (referans) evapotranspirasyonun da artmasına karșın, toprak koșulları ve sulama uygulamaları dikkate alındığında topraktaki nem miktarının azalacağı ve böylece bitkiden olan terleme ile topraktan olan buharlașmanın da azalacağı görülmektedir. Ayrıca, bu durumun oransal verimlere yansıyacağı ve diğer biyolojik parametrelerin değișmediği varsayıldığında verimlerde de azalmaların olacağı tahmin edilmektedir.

\section{SONUC̣LAR}

Küresel ısınmadan kaynaklanan İklim değișiminin, en çok tarım sektörünü etkileyeceği yadsınamaz bir gerçektir. Sıcaklık artıșı ve yağıș azalmasının öngörüldüğü Ege Bölgesinde, tarımsal verimliliğin doğrudan etkileneceği düșünüldüğünde, iklim değișikliğinin toprak nemi üzerindeki etkilerini inceleyen proje sonuçlarının, gerek bölgesel ekonomiye ve gerekse kırsal kesimdeki sosyal refaha etkilerinin büyük olacağı tahmin edilmektedir. Kısa sürede değiștiremeyeceğimiz ve dünyanın büyük bir bölümünü etkileyecek olan olası iklim değișiminin sonuçları ile bașa çıkabilmemiz, ancak onu, izleyebilmemiz ve eğer varsa alınabilecek önlemleri alabilmemize bağı olacaktır.

Bu çalıșmada, iklim değișikliğinden en çok etkilenecek yörelerden birisi olan Aydın ili ve çevresinde toprak nem dengesini dikkate alan bir model (SWAP) gerçek zamanlı olarak yürütülmüș ve geçerliliği test edilmiștir. Elde edilen sonuçlar, modelin Aydın yöresi iklim ve toprak koșulları için toprak nem dengesini simüle etmede bașarılı olarak kullanılabileceğini göstermiștir. 
Toprak nem dengesini olușturan toprak ve bitki özellikleri ile atmosfere ilișkin parametreler kullanıldığında, geleceğe ilișkin olası iklim değișikliğinin toprak nem dengesi üzerindeki etkileri ve değișiminin kestirilebileceği ortaya çıkmıștır. Bu sonuçlara göre, Aydın yöresinde özellikle sıcaklık artıșı ile atmosferin buharlașma talebinde önemli artıșlar olacağı ve bu durumun buharlașma ve terlemeyi içeren bitki su tüketimlerini oldukça artıracağı görülmüștür. Bitkiden olan terlemenin artması yanında, topraktan olan buharlașmanın da artması, özellikle yüksek taban suyu olan yörede kapilar yükselme ile bitki kök bölgesine daha fazla nem akıșının olacağı model çıktıları ile anlașılmıștır. Topraktaki nem dengesinin, bitki gelișme dönemi boyunca topraktaki dikey su hareketine veya akımlara bağlı olduğu, ancak, bu durumun su sağlama olanakları ile uyumlu olmaması durumunda toprakta depolanan nemde ve tarımsal verimlilikte önemli azalmaların olacağı tahmin edilmektedir.

Bundan sonraki çalıșmalar, farklı toprak tiplerini ve farklı ürünleri içeren geniș alanlarda bu tür model çalıșmalarının yapılmasına yönlenmelidir. Geleceğe dönük iklimsel öngörüler ıșığında toprak nem durumu, bitki su gereksinimi ve olası ürün desenlerinin belirlenmesine yönelik araștırma faaliyetleri, olası iklim değișikliğinin etkilerini değerlendirebilmemize ve tarımsal açıdan hazırıkıı olmamıza olanak sağlayacaktır.

\section{KAYNAKLAR}

Anonim (2013) http://mww.karadastarim.com/bayerbitki-koruma/pamuk-tohumlari/Claudia

Aydın M, Yano T, Evrendilek F, Uygur V (2008). Implications of Climate Change for Evaporation from Bare Soils in a Mediterranean Environment. Environmental Monitoring and Assessment, Volume 140, Numbers 1-3, 123-130, DOI: 10.1007/s10661-007-9854-4,

Bastiaansen W G M, Singh R, Kumar S, Schakel J K, Jhorar R K (1996). Analysis and Recommendations for Integrated on-farm Water Management in Haryana, India: A Model Approach, 118, DLO Winand Staring Centre for Integrated Land. Soil and Water Research, Wageningen, Netherlands.

Belmans C, Wesseling J G, Feddes R A (1983). Simulation of the Water Balance of Acropped Soil: SWATRE. Journal of Hydrology, 63, 271-286.

Çaldağ B, Șaylan L (2005). Sensitivity Analysis of the CERESWheat model for Variations in CO2 and Meteorological Factors in Northwest of Turkey. Int. J. Environ. Poll. 23, 3, 300-313.

Droogers P (2000). Simulation Models to Assess Water Productivity at Different Scales, International Water Management Institute, Colombo, Sri Lanka.
Droogers P, Van Dam J C (2002). Field Scale Adaptation Strategies to Climate Change to Sustain Food Security: A Modeling Approach Across Seven Contrasting Basins, IWMI Working Paper, International Water Management Institute, Colombo, Sri Lanka.

FAO (1998). Crop evapotranspiration - Guidelines for Computing Crop Water Requirements - FAO Irrigation and Drainage Paper 56, Food and Agriculture Organization of the United Nations, Rome.

IPCC (2007a). Climate Change, Synthesis Report, Valencia, Spain.

IPCC (2007b). Regional Climate Projections, Europe and Mediterranean Region (Chapter 11): Fourth assessment Report, pages 848-940.

Kanber R, Kapur B, Ünlü M, Tekin S, Koç D (2007). İklim Değișiminin Tarımsal Üretim Sistemleri Üzerine Etkisinin Değerlendirilmesine Yönelik Yeni Bir Yaklașım: ICCAP Projesi, TMMOB 2. Su Politikaları Kongresi, Ankara, sayfa 83-94.

Kayam Y, Ozsoy Ü, Lomas J, Öden O, Mandel M, Gurbuz M (2002a). The Impact of Climatic Change on Wheat Production of Aegean Region in Turkey: The Effect of Reduction of Rainfall and the Increase of Temperature on Wheat Yields. CLIMAGRImed Workshop, www.fao.org/sd/ climagrimed, FAO, Rome, Italy.

Kayam Y, Beyazgül M, Droogers P (2002b). A Model Approach to Evaluate Irrigation System Water Balance; An Example from Gediz Basin. International Journal of Water, Volume 2, No. 2/3, Oxford, UK.

Kayam Y, Mandel M, Lomas J (2006). The interpretation of the Simulated Soil Moisture Balance; The Impact of Climate, Agrotechnology, Soil and Socio-economic Factors on Cotton Yields - Turkish-Israel Joint Research Project Final Report, Menemen-İzmir, Chapter pages 58-61.

Kite G, Droogers P (2000). Comparing Estimates of Actual Evapotranspiration from Satellites, Hydrological Models, and Field Data: A Case Study from Western Turkey. International Water Management Institute, Research Report 42. Colombo, Sri Lanka.

Korkmaz N, Kayam Y, Gündüz M, Acar C O, Sen S, Bilir Z L, Avcı M, Așık Ș, Ünal B (2009). Menemen Sol Sahil Sulamasında Tersiyer Kanal ve Tarla Düzeyinde Su Dağıım Performansının Değerlendirilmesi, Menemen Toprak ve Su Kaynakları Araștırma Enstitüsü Yayınları, Sonuç Raporu, Yayın No: 246

Kömüșcü A Ü (1998). Implications of Climate Change for Soil Moisture Availability in Turkey's Southeastern Anatolia Project Region, Drought Network News, University of Nebraska - Lincoln DigitalCommons@University of Nebraska - Lincoln.

Robock A, Vinnikov K Y, Srinivasan G, Entin J K, Hollinger S E, Speranskaya N A, Liu S, Namkhai A (2000). The Global Soil Moisture Data Bank. Bull. Amer. Met. Soc., 81, 12811299.

Uğurlu Ö, Örçen i (2007). Küresel Isınmanın Türkiye'nin Enerji Kaynaklarına Olası Etkileri, TMMOB Türkiye VI. Enerji Sempozyumu- Küresel Enerji Politikaları ve Türkiye Gerçeği, Ankara. 
Van Dam J C, Feddes RA (2000). Simulation of infiltration, evaporation and shallow groundwater levels with the Richards' equation. J. of Hydrol., 233, 72-85.

Van Dam J C, Huygen J, Wesseling J G, Feddes R A, Kabat $P$, van Walsum P E V, Groenendijk P, van Diepen $C$ A (1997). Theory of SWAP version 2.0. Simulation of water flow, solute transport and plant growth in the Soil-WaterAtmosphere-Plant environment.
Van Genuchten, M Th, (1980). A closed form equation for predicting the hydraulic conductivity of unsaturated soils. Soil Sci. Soc. Am. J., 44, 892-898.

Wösten J H M, Veerman G J, de Groot W J M, Stolte J (2001). Water retention and hydraulic conductivity functions of top- and subsoils in The Netherlands: The Staring series. Alterra report 153, Wageningen, The Netherlands, 86 p. (in Dutch). 